\title{
Exploring the decision to adopt International Financial Reporting Standards early: The case of International Financial Reporting Standards 13
}

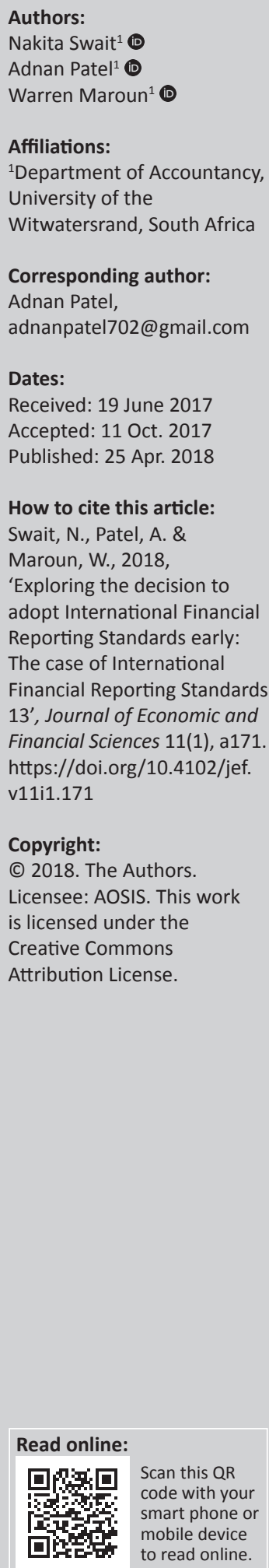

\begin{abstract}
Using an exploratory interpretive research approach and International Financial Reporting Standards (IFRS) 13 as a case study, this article investigates the factors that affect the decision to adopt a specific IFRS early. The research findings are significant as very little interpretive research has been performed on financial reporting from a South African perspective. The findings reveal that the majority of the interviewees did not elect to adopt IFRS 13 early. Technical constraints - such as the need to provide additional accounting disclosure discouraged the early adoption of the standard. Factors such as the effect of adoption on earnings, decisions made by competitors and the relevance of the standard to business operations were also considered as part of this decision. Perhaps most significant is the logic of resistance to new standards evidenced by a general dismissal of the view that IFRS 13 provides more useful information to users of financial statements.
\end{abstract}

\section{Introduction}

Research shows that there are benefits of voluntarily adopting International Financial Reporting Standards (IFRS) (Barth et al. 2013; Brown \& Tarca 2011; Daske et al. 2006). This article uses IFRS 13 as a case study to evaluate the subtle characteristics of IFRS standards which result in South African preparers electing to adopt a standard before its effective date.

IFRS 13 was implemented in January 2013. It clarifies how to measure fair value rather than expand the use of fair value accounting (Tran 2012). As noted by Tran (2012), the aim of implementing a standard governing fair value is to clarify how to determine fair value and provide consistency across all IFRS pronouncements. An increase in clarity and consistency implies an increase in comparability of the financial information (International Accounting Standards Board [IASB] 2011). This raises the question: would preparers of financial information elect to adopt IFRS 13 early? This study investigates what factors affected the decision to adopt the standard early or refrain from doing so, as opposed to focusing on the technical difficulties of the standard.

Although previous research considers the adoption of IFRS by developing countries, such as South Africa (Zeghal \& Mhedhbi 2006; Zehri \& Abdelbaki 2013), the focus is on the adoption of IFRS as a whole rather than a specific standard. In addition, these studies are based on available quantitative data from the year in which IFRS was adopted. In contrast, this study performs interpretive research, relying on detailed interviews, to identify the factors at play when adopting a specific standard early. The findings are significant as very little interpretive research has been performed on financial reporting from a South African perspective. As a result, this study addresses the need for practical fieldwork studies on financial reporting (Brennan \& Solomon 2008; Maroun \& Jonker 2014).

\section{Literature review}

In order to assess what factors preparers of financial information consider when deciding whether to adopt a standard early or not, prior research is used to provide a frame of reference. As little research has been conducted on adoption of a particular standard; the adoption of IFRS as a whole has been considered below to form a basis for further discussion.

\section{Staff training and the role of auditors}

In a study performed by Jermakowicz and Gornik-Tomaszewski (2006), respondents stated that a lack of knowledge, education and training on IFRS proved to be a challenge when converting 
to IFRS. Respondents were of the opinion that, in order to adopt IFRS, training programmes were needed (Capkun, Collins \& Jeanjean 2012). These training programmes are necessary on an ongoing basis and audit firms can play a vital role in providing adequate training. The need for auditor assistance was owing to many entities lacking the relevant financial accounting expertise.

As staff training proved to be a critical factor to convert to IFRS, interviewees participating in this study were questioned on whether or not staff training remained relevant for the decision to adopt IFRS 13 early.

\section{Implementation guidance and interpretation of the standards}

The main difficulties in implementing IFRS in entities listed in the European Union (EU) include the complex nature of IFRS, the lack of IFRS implementation guidance and lack of uniform interpretation (Capkun et al. 2012; Jermakowicz \& Gornik-Tomaszewski 2006). An implementation guidance is provided when standard setters expect difficulties in applying a new standard. The implementation guidance does not form part of the standard itself and is usually issued as an entirely separate document (IASB 2011). When implementation guidance is not provided, by the IASB, preparers often look to US GAAP or national GAAP for guidance, resulting in a decrease in comparability of financial information (Schipper 2005).

In this context, this article assesses whether or not implementation guidance and a lack of uniform interpretation of IFRS 13 affected the decision of local preparers to adopt the standard before its effective date.

\section{Cultural, educational and economic factors}

The adoption of IFRS by developing countries, such as South Africa, may depend on a number of factors, namely, economic growth, level of education of preparers of financial information, the degree of external openness, cultural membership and the existence of a capital market (Zeghal \& Mhedhbi 2006). The existence of a mature financial market and preparers' cultural membership are also factors that significantly affect the decision to adopt IFRS standards (Khlif, Hussainey \& Achek 2015; Zeghal \& Mhedhbi 2006). In contrast, economic growth and external economic openness may not necessarily affect the decision to adopt accounting standards early (ibid). According to Zehri and Abdelbaki (2013), a common-law legal system is more important for the decision to adopt IFRS in developing countries, while the political system may have no significant effect on the decision to adopt IFRS. Zehri and Abdelbaki (2013) also question the relevance of preparers' culture and education and the stage of development of the capital market for the decision to adopt IFRS.

As the prior research has reported mixed results on the relevance of education, culture and economic factors for the decision to adopt IFRS, these are specifically considered in this study.

\section{Accounting disclosure}

IFRS applies a principles-based approach and common-law institutional logic to accounting which requires more disclosure of information and restricts accounting choices available to managers using IFRS than most local accounting standards (Ashbaugh 2001; Guerreiro, Rodrigues \& Craig 2012). IFRS encourages less accounting discretion, higher levels of transparency, higher accounting quality and a loss of private benefits for company insiders (Ashbaugh 2001; Guerreiro et al. 2012). As there is less discretion allowed in IFRS compared to other local standards, there is less responsiveness to adopt IFRS early (Guerreiro et al. 2012). This is contrary to the findings in Ashbaugh (2001) who found that firms were more likely to disclose financial information under IFRS as it allows greater flexibility in terms of accounting measurement choices and requires fewer disclosures than US GAAP. Other studies show that preparers of financial information appear to be particularly concerned about providing additional accounting disclosure owing to a loss in competitive advantage (Gietzmann \& Trombetta 2003; Wagenhofer 1990).

As there is uncertainty about the costs and benefits of the additional accounting disclosure required by IFRS (something which IFRS 13 deals with extensively), this factor is included in the interview agenda.

\section{National versus international regulations}

As a number of South African listed entities are listed in the EU (JSE 2013), it is necessary to consider the effects that regulations in these foreign countries have on an entity's ability to adopt a standard early. Before adopting new standards, the EU follows an endorsement process in order to ensure that the standard will improve financial reporting (Abela \& Mora 2012; Brown \& Tarca 2011; Delvaille, Ebbers \& Saccon 2011). The European Commission continues to pressure the IASB to indicate the expected effects of the standards being set although the process of adopting standards is not automatic (Abela \& Mora 2012; Brown \& Tarca 2011). Accordingly, it is for the relevant local accounting body to determine whether or not to adopt a new or amended standard. This has created inherent tension as capital markets are increasingly becoming more global, while regulations rely on local processes (Abela \& Mora 2012). To add to the complexity, listed companies are only required to use IFRS for their consolidated accounts. Individual or separate financial statements may use another basis of accounting (Larson \& Street 2004). Each EU country is given the option of whether IFRS will be required or allowed in the preparation of listed companies' individual accounts (as approved for use in the EU) and non-listed companies consolidated and or individual accounts (Larson \& Street 2004). 
This provides evidence that EU regulations may have a significant impact on an entity's decision to adopt IFRS standards early. As the EU is required to endorse a standard before it can be adopted by an entity (Abela \& Mora 2012), this may affect a South African entity with a parent company in the EU from early adoption of a standard. This is analysed in more detail during the interview process.

\section{Earnings management}

Numerous studies have found that earnings management plays a key role in an entity's decision to adopt a standard (e.g. Barth, Landsman \& Land 2008; Bartov, Goldberg \& Kim 2005; Capkun et al. 2012; Christensen, Lee \& Walker 2007; Daske et al. 2006). Earnings management is defined as a reasonable and legal decision-making and reporting by management intended to achieve stable and predictable financial results (Thomson 2013). Earnings management is not necessarily illegal but there can be a fine line between earnings management and fraudulent misrepresentation of financial information (Thomson 2013). Benefits and incentives to manage earnings within financial statements include: smoothing earnings to suggest that financial performance is stable over time and encourage higher share prices; boosting management credibility; and managing analysts' expectations and personal incentives for managers (Bergstresser \& Philippon 2006; Degeorge, Patel \& Zeckhauser 1999; Hunt 1997; Rosenfeld 2000).

There is a large body of research dealing with the determinants and consequences of earnings management when firms' change their basis of performance (e.g. Barth et al. 2008; Bartov et al. 2005; Capkun et al. 2012; Christensen et al. 2007; Daske et al. 2006). The extent to which earnings management is relevant when a firm choses whether or not to adopt a specific accounting standard is not dealt with in detail and needs to be evaluated further.

\section{Compliance with International Financial Reporting Standards}

In the year in which IFRS is adopted by an entity, it provides very little narrative disclosure on the change, suggesting that the conversion to IFRS has little relevance for overall business operations (Stent, Bradbury \& Hooks 2013). In line with these findings, Hopwood (1987) finds that many preparers of financial information are of the opinion that accounting is limiting and laborious and is independent of business operations. In a similar light, accounting is increasingly seen by preparers of financial information to be more compliance-driven rather than a reflection of the 'underlying processes and forces at work' (Hopwood 1987:207). Consequently, the researchers focused specifically on whether or not South African preparers felt that IFRS 13 is unrelated to their business activities and if this had an impact on the decision to adopt IFRS 13 early or refrain from doing so.

\section{Standards for different industries}

Standards used for different industries are equivalent to a business model approach. This approach to accounting, although not specifically defined by the IASB (2013), has been described by dissenting Board members as:

... the chosen system of inputs, business activities, outputs and
outcomes that aims to create value over the short, medium and
long-term. (p. 3)

This approach is increasingly used by the IASB, resulting in changes to the accounting for financial instruments, investment property, inventory, fixed assets and segmental reporting (Danjou 2013; IASB 2013). Notable shortfalls of a business-model-inspired accounting method include the reduction in comparability and less neutral information being conveyed to users as the accounting can encourage preparers to show the most favourable outcome (IASB 2013). As a business model approach to accounting is an area currently under debate, interviewees are asked whether the absence of a business model approach in IFRS 13 affects their decision to adopt or not adopt IFRS 13 before its effective date.

\section{Resistance}

Resistance to IFRS is evidenced by an unwillingness to adopt or comply with a standard or accounting system (Saidin, Badara \& Danrimi 2014; Van Zijl \& Maroun 2017). Resistance to adopting IFRS arises because of doubts regarding the 'uniform suitability and relevance [of IFRS] in diverse economic, political and institutional settings across the globe' (Saidin et al. 2014:295).

Research shows that resistance manifests itself in the decision to delay the introduction of new prescriptions because of a belief that management's existing practices are adequate (Tremblay \& Gendron 2011). Governance-related prescriptions (such as IFRS) are often met with a logic of resistance as preparers of financial statements respond to new accounting standards as an exercise in compliance with the rules rather than as a means of improving the quality of the reporting process (Tremblay \& Gendron 2011). The adoption of a new IFRS standard, thus, becomes an exercise in paying lip service to accounting regulation because the accounting developments are not seen as directly relevant for the organisation or its stakeholders (Gelter \& Kavame 2014). In some cases, however, there is less resistance to IFRS by investors and CFOs because of an increased understanding of the applicable standards, as well as a change in attitude about IFRS (Liu et al. 2011; Van Zijl \& Maroun 2017).

Because of the fact that many jurisdictions, including South Africa, mandate compliance with IFRS for listed companies (Companies Act No. 71, 2008), it is possible that resistance manifests itself in a decision to delay the early adoption of IFRS. As such, the possibility of resistance influencing the decision to adopt IFRS 13 early is discussed with interviewees. 


\section{Competitors}

Another factor when electing whether or not to adopt a standard early is a company's competitors (Gietzmann \& Trombetta 2003; Holthausen \& Leftwich 1983; Wagenhofer 1990). Studies show that preparers of financial information can minimise decision-making costs by copying their competitors' accounting methods or arguing that a given accounting approach is defined by industry norms (Holthausen \& Leftwich 1983; Collin et al. 2009). Another reason provided for following industry reporting trends is that deviations from these trends could be interpreted as a negative signal to suppliers and labourers (Collin et al. 2009). This raises the question: Do preparers of financial information in South Africa follow adoption patterns of competitors in order to avoid unintentional signals to users of the financial statements? As competitive advantages are perceived to decrease with additional disclosure of financial information, and as IFRS 13 specifically requires additional disclosure, the role of disclosure and competitors in an entity's decision to adopt IFRS 13 early is examined in detail.

\section{Methodology}

As discussed in the 'Introduction' section, there is a large body of work which deals with the adoption of IFRS as whole (Barth et al. 2013; Brown \& Tarca 2011; Daske et al. 2006), but only few articles deal with the decision to early adopt a specific accounting standard. As a result, an interpretive approach, relying on a qualitative method, was considered most appropriate for the purposes of this study (O'Dwyer, Owen \& Unerman 2011). Detailed interviews allowed the researchers to gain an in-depth understanding of the decision to adopt IFRS 13 early or refrain from doing so based on first-hand accounts from accounting experts (Creswell 2003; Williams 2007).

A semi-structured interviewing process was used to explore the opinions of the interviewees (Qu \& Dumay 2011; Rowley 2012). This involved the preparation of questions based on a number of central themes identified from the literature as explained in the 'Literature review' section. The participants interviewed were CFOs and financial managers working in public listed companies in South Africa (preparers). This group of interviewees was purposefully selected because companies listed on South Africa's stock exchange are required to prepare financial statements in compliance with IFRS. Further, preparers working for listed entities will have first-hand experience with these standards and the voluntary adoption. Five preparers from four organisations participated in the study. The participant firms all operate in the consumer and industrial products and services industries. The industries specifically excluded from this study are the banking, insurance and mining industries. This is because these industries require additional industry-specific reporting requirements (see IASB 2011). Hence, the views and findings from this study cannot be generalised to the other industries. In addition, audit managers and partners of the 'Big Four' audit firms (PricewaterhouseCoopers, Deloitte, EY and KPMG) have also been selected as interviewees for this study (audit experts). These participants are actively involved in the audit function of JSE-listed entities. Furthermore, audit experts are involved in reviewing the decision-making process of JSE-listed entities and making recommendations regarding the adoption and application of IFRS. As a result, these participants have first-hand knowledge of how companies are internalising the requirements of IFRS and can provide significant insights for the purpose of this study. Five audit experts participated in the study.

As recommended by Rowley (2012), a total of 10 interviews were performed ranging from 45 to $90 \mathrm{~min}$ in length. The number of interviews conducted was driven by the need to achieve saturation which occurred after the seventh interview. This was evidenced by the repetition of responses received. As such, no further interviews were considered necessary, but the researchers decided to extend the sample to 10 respondents to ensure that no additional reasons for adopting or not adopting an IFRS early were identified. In keeping with the interpretive spirit of this study, data saturation was obtained by relying on a smaller number of high-quality interviews rather than trying to maximise the number of respondents (Tuckett 2004). Nevertheless, the relatively small sample size may be seen as a limitation of this research.

Data analysis followed a three-step approach: data reduction, data display and verification (O'Dwyer et al. 2011). The transcribed interviews were then analysed in-depth to identify key themes (Leedy \& Ormrod 2010; Rowley 2012). These key themes were developed from prior literature and updated as additional information that emerged from the interview process. In order to make sense of the data and to avoid any bias in interpretation, two researchers were actively involved in the interview and interpretation process. In addition, where contradictions were noted in an interview, follow-up questions (via email) were used to clarify the respective respondent's views (O’Dwyer et al. 2011; Rowley 2012).

Throughout the interview process, it was necessary to reconsider all the data received from the interviews in order to ensure that all themes were identified and correctly interpreted (Tuckett 2004). This allowed the researchers to identify different opinions on the reasons for adopting or not adopting IFRS 13 early.

\section{Findings}

Interviewees discussed a number of factors that were relevant for deciding whether or not to adopt IFRS 13 early. These were aggregated by the researchers and are presented below. The order in which the factors are presented does not necessarily indicate their importance or relevance. In general, audit experts and preparers discussed the same factors. There were no discernible differences between the two respondent groups. Finally, the same factors were considered by respondents who decided to adopt IFRS 13 early and those who chose not to do so. The only difference was that early adopters felt that the 
benefits of applying IFRS 13 before its effective date would exceed the costs of early adoption, while those who delayed application held the opposite view.

\section{Staff training and the role of the auditor}

Staff training seems to have played a role in the decision to adopt IFRS 13 early for some preparers. Training was necessary to ensure that staff members were up-to-date with the technical aspects and accounting requirements of IFRS 13. Preparers of financial information look to auditors for this technical training, stating:

'When we became aware of [IFRS 13], we actually scheduled a meeting with our auditors because our accounting is not the straightforward manufacturing; our accounting is a bit more complex. We actually scheduled specific training for our entity just to make it more specific to us and our entity.'

In this light, an audit expert noted:

'Management look to the auditors for [guidance on new standards] ... [So] we do liaise with management to inform them of the new accounting standards which they should look out for and start planning for.'

Technical training provided by auditors does not suggest that auditors should advise whether or not a standard should be adopted early or make managerial decisions in this regard. To the contrary, this training provides assistance to the preparers of financial information so that they can make their own decisions. Moreover, it appears that the auditors play an informative rather than prescriptive role to ensure that preparers are aware of possible effects on the entities. As a result, the role played by auditors is supportive in nature. Although interviewees admitted to keeping the need for staff training in mind when deciding whether or not to adopt a standard early, interviewees did not feel that this was a dominant factor in their decision. This appears to be inconsistent with Jermakowicz and Gornik-Tomaszewski (2006) who find that staff training is the main difficulty when adopting IFRS. The different finding reported in this study may arise owing to the training auditors provide to clients. In addition, because preparers are only adopting a single IFRS (rather than IFRS as a whole), training is a less important factor when deciding whether or not to adopt IFRS 13 before its effective date.

\section{Implementation guidance and interpretation of the standard}

Except for one interviewee, respondents were unanimous that the implementation guidance supporting IFRS $13 \mathrm{did}$ not play a role in the decision to adopt the standard early. One interviewee stated:

'Guidance material typically doesn't go through the same process; it doesn't get the same attention from the Board, if the Board even looks at it. So it might be a staff member's view on how to adopt a certain standard which is a very challenging place to be. I think where guidance is necessary, there is enough.'
Most interviewees found that, in applying IFRS 13, material interpretation issues were not identified and that adequate interpretation guidance was provided by the IASB. These findings are contrary to those of Jermakowicz and Gornik-Tomaszewski (2006) who noted that the key challenges of converging to IFRS was its complexity, the lack of implementation guidance and the lack of uniform interpretation. As explained in the on 'Staff training and the role of the auditor' section, this difference is probably because preparers are only evaluating whether or not to adopt a specific accounting standard early rather than IFRS as a whole. In addition, it should be noted that the aim of IFRS 13 is to clarify fair value measurement. The standard does not change the specific accounting treatment required by other standards (Tran 2012). For this reason, the changes to IFRS 13 are not profound and should (theoretically) not require additional implementation guidance. Where more complex standards are implemented, it is understood that guidance should still be provided.

\section{Cultural, educational and economic factors}

All interviewees were unanimous in stating that cultural, educational and economic factors did not play a role in the entities' decision to adopt IFRS 13 early. One particular interviewee felt the financial reporting was in a very mature phase, not allowing other factors to contribute to such a decision:

'I think our [South Africa's] financial reporting environment is very mature. We have been on IFRS for many years and the first guys to take the leap on SMEs, [we are also] one of the only countries that has a really good integrated reporting framework. So I think that we are very mature from a financial reporting perspective. So I don't think that it is about an education issue or a maturity issue at all.'

To date, the South African accounting profession is recognised internationally for its strength in reporting standards (Marais 2008; Maroun, Coldwell \& Segal 2014; Verhoef 2012). As a result of South Africa's proactive approach to corporate reporting, the involvement with the IASB and the education and training programmes for entry to the accounting profession, South Africa has become a leader in financial reporting (JSE 2013; Verhoef 2012). As a result of the maturity of the reporting environment, interviewees agreed that economic factors, such as the existence of a welldeveloped or sufficiently deep financial market, do not play a significant role in an entity's decision to adopt a particular accounting standard. The same was true for cultural issues and the training and education of preparers.

It should, however, be noted that interviewees have similar professional backgrounds and come from a single jurisdiction making it difficult to conclude definitively on the effects of cultural, educational or economic factors on the decision to adopt IFRS 13 early. Related to this, a small sample size means that findings cannot be generalised. Finally, most of the prior research which finds that cultural, educational and economic factors affect the corporate reporting deal with 
adoption of entire reporting standards rather than a single accounting standard (Khlif et al. 2015; Maroun 2015). As a result, the extent to which culture, education and economic context influence the decision to adopt IFRS 13 early will need to be dealt with by future researchers.

\section{Accounting disclosure}

Preparers of financial information found that the additional accounting disclosures play an important role in deciding whether or not to adopt IFRS 13 early:

'To have early adopted, you have to have provided that disclosure and that would be seen as a barrier to early adoption.'

This statement is important because the introduction of IFRS 13 has resulted in an increase in disclosure (IFRS Foundation 2013; Tran 2012). The views generally expressed by the interviewees indicate that there is a perceived administrative burden associated with early adoption. This is iterated by Wagenhofer (1990) and Gietzmann and Trombetta (2003). As mentioned previously, IFRS 13 does not change the accounting treatment for fair value measurement (Tran 2012). This provides corroborating evidence which suggests that the administrative burden referred to by the interviewees relates mainly to the additional disclosure requirements of IFRS 13. It is also imperative to note that, at the time of conducting this study, preparers of financial information only had one financial reporting period to apply IFRS 13. This could have been a contributing factor in delaying the adoption of IFRS 13.

\section{National versus international regulations}

International as well as national regulators can play an extremely important role in an entity's decision to adopt accounting standards early:

\footnotetext{
'... One of the other inhibitors is Europe. European companies can only adopt once endorsed by the European regulator so it is not automatic like it is here ... Unless the EFRAG has endorsed, you actually cannot early adopt. So you are stuck between a rock and a hard place because you are stuck in this limbo position where you can't early adopt, particularly if you have European shareholders. So I think that is one of the other issues around early adoption.'
}

This provides evidence that preparers of financial information are restricted from early adoption of new standards depending on the requirements of their ultimate holding company and international regulatory requirements. Contrary to international regulations, it is interesting to note that South African regulators do not play a pertinent role in the decision to early adopt:

'You will see in other jurisdictions that they are a lot more involved in that process. I don't know that [sic] in South Africa they haven't been very interested in the fair value models.'

Other interviewees reiterated these views when deciding whether or not to adopt early:

'... if you look at South African regulators from a financial statement perspective, they do not interfere in financial reporting.
They don't believe it is their place. They will ask questions around information coming out of financial reporting but much more from a regulatory perspective.'

\section{Earnings management}

When interviewees were asked if they managed their earnings, preparers unanimously responded in the negative. This result is to be expected. When, however, interviewees were probed on the impact which a new standard might have on reported profits, it became clear that companies are aware of the effect which accounting standards have on earnings and take this into account when deciding whether or not to adopt an accounting standard early. For example, when explaining their views on delaying the introduction of IFRS 13, two preparers pointed out:

'It depends on the nature of the client and [whether] it bring $[s]$ about volatility in earnings. I think where you have [volatility in earnings] the clients will take a different approach on whether to early adopt or not.'

Similarly:

'We need to assess what the impact [of a new standard] is [on our financial statements] ... if [ a new standard] is going to have an impact on profit and loss and earnings per share and the competitors are not disclosing the same information ... that is where comparability will be influenced.'

These interviewees have indicated two important points. Firstly, the approach taken regarding early adoption is dependent on the effect this will have on the reported earnings for the entity. Secondly, managers like earnings to be stable. This finding is in line with Hunt (1997) who finds that lower earnings volatility results in higher earnings persistence. This suggests managements' preference for smooth earnings consistent with Rosenfeld (2000). A possible reason for wanting to smooth earnings is the desire to meet or beat market expectations (Bartov et al. 2005).

IFRS 13 does not introduce a requirement to use fair value accounting. It provides guidance on how to measure fair value when required by another standard and stipulates additional disclosure requirements (IASB 2011). Nevertheless, respondents agreed that formalising the measurement of fair value and related disclosures can result in changes in reported earnings and the manner in which these are presented in the financial statements. In turn, this can affect users' perception of the risk associated with particular fair value measures (see van Zijl \& Maroun 2017). This is particularly relevant for listed entities whose share prices are directly affected by these perceptions. The desire to meet expectations in order to maximise share price is evident through an interviewee's reference to being a listed entity:

'I think you need to consider that because we are a listed entity you always need to look at the market and what does the market expect. If I have a bad year this year and I can early adopt a standard that can tank [the earnings within the entity], for example [by] R50 million profits, I would be stupid to do it because then I would end up with nothing on my income statement. Even if it 
something that $[i s]$ include $[d]$ and exclude $[d]$ for HEPS. I think we would always look at what the financial position of the company and look at the financial effect of that specific standard or interpretation is going to be on the financial statements. And then we still try and see when to do it.'

Overall, while interviews did not admit to purposefully managing earnings, they confirmed that market expectations play a vital role in deciding whether or not to adopt an accounting standard (such as IFRS 13) early. In addition, where competitors have not early adopted a particular standard, entities are reluctant to be the first to 'take the plunge for fear of market reactions' (see also the 'Competitors' section). For example, one interviewee, who felt that she was a market leader and was inclined to adopt IFRS 13 early, delayed doing so because her competitors had not early adopted the standard and there was a concern that the market would misinterpret the decision to apply IFRS 13 before the effective date.

\section{Compliance with International Financial Reporting Standards}

Accounting is often seen to be a compliance exercise that is independent of the business operations (see the 'Literature review' section). Interviewees had mixed views on this point. Most believed that some aspects within IFRS had a clear link to business operations. Consider, for instance, the following comment:

'There is definitely a link to business operations. For example, for the defined benefit plans I mentioned earlier, this standard gave us information about a liability within our business that we were not aware of. So this information can tell us things about our business that we didn't know and provide us with guidance on how to account for this.'

This statement highlights the 'active role' that financial reporting and IFRS can play in an entity's operations 'actively shaping organisational affairs' (Hopwood 1987). This view was iterated by the following interviewee specifically with regards to IFRS 13 and its effects on business operations:

I think it [IFRS 13] is very relevant because management then knows how to run the operations. So they can see, for example, where the value is, where the volatility is, etc., and then direct more resources in managing those resources of the business. (p. 212)

Nevertheless, interviewees also felt that many standards are not always important for their financial statements. This arose owing to the particular standard having little relevance for their entity. As such, application of the IFRS becomes a compliance exercise:

'I think some of the things [are] just compliance. Like IFRS 13 for example - it has a minimal effect on our business but we still have to apply $[i t] . '$

In other words, when IFRS 13 was not seen as directly relevant owing to the limited number of fair value measures currently in use by the respective firm, the decision to adopt IFRS 13 early was not justified on the basis of the business operations or the information needs of the users. Interviewees felt that the importance of providing added information by means of additional disclosure is not a primary consideration. Instead, early adoption was justified on the grounds that the standard is not expected to have a significant effect on their operations. When IFRS 13 was seen as directly relevant to the entity owing to more frequent use of fair value measurements interviewees appear to have merely applied the 'rules' in IFRS 13 rather than using professional judgement to assess the impact that the standard may have on their particular entity and how users would benefit from the decision to adopt the standard early.

\section{Standards for different industries}

A number of the interviewees referred to the concept of different reporting standards for different entities. There is an element of compliance driving the application of IFRS. Respondents questioned whether it would be more suitable to amend standard requirements to allow leeway for the different industries. Although the practical issues of such standards were considered and debated, interviewees unanimously agreed that this would be an ideal option.

In one instance, an interviewee who worked in a manufacturing firm questioned whether it was necessary for them to disclose the same information that a consulting firm discloses. As the manufacturing entity relied significantly on property, plant and equipment, the interviewee considered it necessary to disclose additional information relating to these assets. On the contrary, the interviewee stated that a consulting firm should not need to provide this additional detail as those assets were not part of the core of business operations. In agreement with this, other interviewees stated that disclosure of additional information required by IFRS adds significant amounts of unnecessary work which does not necessarily reflect the operations of their business. These interviewees were of the opinion that industry-specific standards would reduce this compliance burden. Consider the following comments:

'IFRS needs to be tailored to the business and if [the standard] is not applicable and it doesn't affect the users' judgment [it should not be required to be disclosed].'

'... [Industry-specific standards] would provide more relevant information to users in general. I think that is the way forward if IFRS wants to remain relevant.'

These views point to the benefits of a business model approach (Maroun 2017). Benefits emphasised include assessing the resources of the business, as well as assessing how management has discharged its responsibilities to use these resources. Together with this, interviewees felt that they may be more inclined to voluntarily adopt standards that were more relevant to their industry. Another interviewee reiterated the need for more industry-specific and entity-specific financial information by using an example of UK GAAP:

'In the UK they have changed their national GAAP and brought in a new UK GAAP. And what they did is they based it on IFRS for SMEs. And now that has no disclosure for financial standards nothing like IFRS 13. So it has all the principles of IFRS 13 from 
a measurement side but then none of the disclosure. Then they said that they were not happy with that and then they put in additional disclosure for financial institutions. So there you have it two-tiered. And I think that there is a lot of merit in that. The thing we can't forget is that we have these big accounting teams at the big institutions who can churn out these disclosures. What about the next tier down - the subsidiary of a big international corporation? What about big privately held companies? IFRS for SMEs is not for everyone so you either have no disclosure or all this disclosure.'

\section{Resistance}

Fair value accounting has been a requirement found in different accounting standards for a number of years (Bushee 2001; Shaffer 2010). Nevertheless, interviewees showed some resistance to fair value accounting.

One way to show dissatisfaction with a particular accounting standard is not to adopt the standard before the effective date. Although interviewees did not explicitly state that they applied a logic of resistance, this was implied by their annoyance with the 'short-term mentality' of the 'investment community':

'I think it has more to do with the investment community, the short-term mentality is the problem here and I think in a way fair value does that and it caters for that because it is for a moment in time. Even if I look at the impairment test and those sorts of things, it is at that moment in time. Is it a fair presentation? At that moment in time, possibly, but that is a short-term view. I don't know if there is a better way of doing it. The further out you look, the less meaning it has anyways, it's hard to balance.'

This appears to be consistent with the findings in Shaffer (2010) who finds that, for assets that are held for short-term profit-making, fair value accounting is the most appropriate method. Where assets are intended to be held for long-term investments, however, fair value accounting 'distort $[s]$ the true financial picture of the investment' (Shaffer 2010:11). Laux and Leuz (2009) find that managers and investors focus on short-term market reactions rather than long-term value creation. As a result of this perceived distortion, interviewees resisted the adoption of IFRS 13. Consider the following examples:

'So in general, my entity does not early adopt any new [standards] or anything like that.'

'I guess the critical thing is [that] I am not sure why anyone would elect to early adopt.'

'... we don't think it adds value and it more likely confuses the uses of financial information.'

'It is not in our nature to adopt. We will adopt when the standard comes into effect.'

These interviewees express doubt about whether or not IFRS 13 provides benefit to the users of financial information. Interviewees also used words such as 'had to', 'force to', 'onerous' and 'burdensome' when referring to the adoption of IFRS 13. This reaffirms that the standard was adopted for compliance reasons rather than a genuine view that it enhanced the usefulness of the financial statements (cf. IASB 2011). In addition:
'... no one wants to take the first leap. No one wants to be the first guy to do it and potentially get it wrong.'

This suggests that early adoption of IFRS standards requires an in-depth understanding of the standard and a willingness to adopt the standard (Liu et al. 2011). Resistance could arise as preparers of financial information are of the opinion that current standards and practices are adequate (Tremblay \& Gendron 2011). One reason for this could include the limited time period to adopt IFRS 13 early (preparers of financial information had one financial reporting period in which to early adopt). There is also some evidence to suggest that the additional disclosure required by IFRS 13 provides more information to third parties which can be used to hold management accountable for their financial reporting practices. In this face of additional scrutiny, there is an element of resistance which is manifested by the decision to delay the adoption (see Gelter \& Kavame 2014; Gietzmann \& Trombetta 2003; Liu et al. 2011; Saidin et al. 2014; Tremblay \& Gendron 2011; Wagenhofer 1990).

\section{Competitors}

During the interview process, all of the interviewees considered the actions of competitors before deciding whether or not to adopt IFRS 13 early. For some interviewees, the actions of competitors appeared to be a dominant consideration while, for others, this appeared superficial. Some of the reasons provided for considering the decisions of competitors included comparability of information between entities within the same industry, delaying the process for additional guidance to be received and an unwillingness to take the lead.

With regards to adopting IFRS 13 early, interviewees said:

'... it is also an unwillingness to be the trail blazer - the one going through all of that and making those decisions on untested accounting literature. Rather everyone just go ahead together.'

'Interpretation and the amount of work is [sic] difficult to assess unless you see what the changes [to the standards] are; so you will see what your competitors are doing and the impact on their numbers before we early adopt.'

These statements appear to be in line with Fields, Lys and Vincent (2001) and Collins et al. (2009) who show that a competitive advantage can be sustained when all competitors provide similar information. In addition, the disclosure required by IFRS 13 can create a barrier to new entrants by setting a high hurdle for minimum levels of disclosure (Gietzmann \& Trombetta 2003; Wagenhofer 1990). Interviewees also mentioned that both global and local competitors would be considered, although the actions of the local competitors would take preference (see Collins et al. 2009; Fields et al. 2001). This is because local competitors are more likely to mimic practices and reduce the firms' advantage, especially when similar products and services are offered to customers (Collins et al. 2009). 
One particular interviewee, who did not elect to adopt IFRS 13 early, stated that the main consideration was the shareholders, although competitors' actions were also relevant:

'But we will consider what our competitors will do. We will also consider [what] the party that we are transacting with do. We will consider what the industry is doing, what the suppliers are doing. But that won't be our overriding decision. The needs of the stakeholders will be overriding.' (IFRS 13)

In addition, when asked why the entity did not adopt IFRS 13 early, the interviewee stated:

'I don't think that there is any benefit for our users in early adopting [as this does not] influence their decisions regarding the company.' (IFRS 13)

This statement also appears to be consistent with Holthausen and Leftwich (1983) who find that, where no significant changes to the accounting standards occurred, entities would mimic the decisions of competitors. This is particularly relevant as IFRS 13 does not change the accounting for transaction and balances; it only clarifies how to measure fair values used in the accounting for these transactions and balances (IASB 2011).

\section{Conclusion}

This study adds to the existing scholarly word dealing with the adoption of IFRS as a basis for preparing financial statements. Much of the prior research discusses the factors that influence the early adoption of IFRS as a whole rather than as a specific IFRS. In particular, the factors that influence the early adoption of IFRS 13 have not explicitly been considered in detail by the IASB and FASB (IASB 2011), and there is no research on the adoption of IFRS 13 by South African companies. As a result, this study makes an important contribution to the academic and professional literature by examining how current international accounting developments are being internalised by South African corporates.

This research finds that the availability of implementation guidance available, differences in the interpretations of the standard, cultural membership, level of education and the maturity of capital markets did not appear to play any role in preparers' decision to adopt IFRS 13 early or refrain from doing so (these views were confirmed by audit managers and partners). The effects of international regulation were, however, relevant. Entities were unable to adopt IFRS 13 until it was endorsed by the applicable regulator when they or their ultimate parent was listed outside of South Africa.

In general, preparers appeared to be unwilling to adopt IFRS 13 early as they felt that this standard was not particularly relevant to their business operations. Their position on IFRS 13 also points to a strong logic of resistance. This logic of resistance was present throughout the interview process. Unsurprisingly, respondents did not expressly state that they would depart from the requirements of IFRS 13 or only apply the standard superficially. Nevertheless, their comments on the challenges of early adoption of the standard suggested that they disputed the view that the benefits of IFRS 13 would
TABLE 1: Factors that influence early adoption decision in the interviewees opinions.

\begin{tabular}{|c|c|c|}
\hline $\begin{array}{l}\text { Major themes identified } \\
\text { through the prior } \\
\text { literature }\end{array}$ & $\begin{array}{l}\text { Did the interviewees find } \\
\text { that these factors } \\
\text { influenced their decision? }\end{array}$ & $\begin{array}{l}\text { Differences in opinions } \\
\text { noted between preparers } \\
\text { and auditors }\end{array}$ \\
\hline Staff training & Yes & No \\
\hline $\begin{array}{l}\text { Implementation guidance } \\
\text { and interpretation of the } \\
\text { standard }\end{array}$ & No & No \\
\hline $\begin{array}{l}\text { Cultural, educational and } \\
\text { economic factors }\end{array}$ & No & No \\
\hline Accounting disclosure & Yes & No \\
\hline Earnings management & Yes & No \\
\hline Compliance with IFRS & Yes & No \\
\hline $\begin{array}{l}\text { Standards for different } \\
\text { industries }\end{array}$ & Yes & No \\
\hline Resistance & Yes & No \\
\hline Competitors & Yes & No \\
\hline
\end{tabular}

exceed the costs. It was also clear that the standard would be applied when it became effective to demonstrate compliance with IFRS rather than because of a belief in the benefits of codifying the measurement and disclosure of fair values.

Preparers of financial information also appeared to be unwilling to adopt IFRS 13 early owing to the potential effects on earnings, as well as the additional information disclosed to competitors. Although interviewees (both preparers and audit experts) denied managing their earnings, they stated that volatility in earnings was a consideration when determining whether or not to adopt IFRS 13 early. This shows the existence of earnings management in the application of IFRS. Together with this, interviewees also appeared to delay the adoption of IFRS 13 owing to the additional disclosure requirements. These disclosures were perceived by interviewees as an erosion of their competitive advantage and also something that would result in added scrutiny and accountability which could be deferred by delaying the application of the new standard.

The findings are summarised in Table 1 by theme identified in the 'Literature review' section and discussed in the 'Findings' section.

Overall, this study addresses the need for practical fieldwork studies on financial reporting. To the authors' knowledge, it is the first to examine early adoption and the effects of IFRS 13 in South Africa. The study identifies a number of factors that influence the adoption of IFRS 13 for South African preparers. Although the study does not prove that these factors influence the early adoption decision exclusively, it does identify factors that South African preparers felt influenced their decision to voluntary adopt IFRS 13. It is, however, important to note the findings presented in this article are subject to limitations.

\section{Limitations and areas for further research}

- The exploratory nature of this study, and the relatively small group of respondents, means that the findings cannot necessarily be generalised. As a result, future researchers 
should examine whether or not the factors identified in this study are applicable to other developing countries and whether or not early adoption of IFRS 13 varies among preparers.

- Related to this, the research has not considered the viewpoints of other stakeholders. Future research will be needed to gain a more comprehensive understanding by considering how the decision to adopt an IFRS early is interpreted by different users of annual and / or integrated reports.

- This study questions neither the objective of IFRS 13 nor its ability to provide relevant and reliable information to users. This should be examined by future researchers.

- It was found that preparers of financial information were reluctant to adopt IFRS 13 early because of additional disclosure requirements. Future researchers should assess whether additional disclosure leads to more review by regulators, auditors and investors, and discourages preparers from providing these disclosures.

- Variations in the responses received from different types of entities such as manufacturing and retail entities were not considered. Future researchers can investigate whether entity types and differences in industry conditions affect the decision to adopt a standard before its effective date.

- Lastly, and related to the above, there is the need to consider whether differences in cultural backgrounds and gender play a role in an entity's decision to adopt specific IFRS.

It is important to note that although a range of participants has been selected for this process, the focus of the interviews is on specific factors that affect voluntary adoption. As such, where audit managers have been interviewed, these managers focussed on specific client knowledge. It is necessary to interview a range of participants owing to a limitation of access to personnel working in listed entities. As a result, secondary information received from audit managers is relied upon. Table 2 provides the number of audit managers and financial managers interviewed.

TABLE 2: Number of audit managers and preparers' of financial information interviewed.

\begin{tabular}{ll}
\hline Audit managers & Preparers' of financial information \\
\hline 6 participants & 6 participants \\
\hline
\end{tabular}

Relatively small sample sizes are inherent to qualitative research (Rowley 2012). Owing to this, it is not possible, to generalize the results of these findings (Creswell \& Clark 2007).

\section{Acknowledgements Competing interests}

The authors declare that they have no financial or personal relationships which may have inappropriately influenced them in writing this article.

\section{Authors' contributions}

N.S. authored the article, A.P. edited the article and W.M. performed the final review.

\section{References}

Abela, M. \& Mora, A., 2012, 'Understanding the consequences of accounting standards in Europe: The role of EFRAG', Accounting in Europe 9(2), 147-170. https://doi.org/10.1080/17449480.2012.720872

Ashbaugh, H., 2001, 'Non-US firms' accounting standard choices', Journal of Accounting and Public Policy 20, 129-153. https://doi.org/10.1016/S0278-4254(01)00025-4

Barth, M., Landsman, W. \& Land, M., 2008, 'International accounting standards and accounting quality', Journal of Accounting Research 46, 467-498. https://doi. org/10.1111/j.1475-679X.2008.00287.x

Barth, M., Landsman, W., Lang. M. \& Williams, C., 2013, Effects on comparability and capital market benefits of voluntary adoption of IFRS by US firms: Insights from voluntary adoption of IFRS by non-US firms, Rock Center for Corporate Governance, p. 133.

Bartov, E., Goldberg, S. \& Kim, M., 2005, 'Comparative value relevance among German, USA, and international accounting standards: A German stock market perspective', Journal of Accounting, Auditing \& Finance 20, 95-119. https://doi. org/10.1177/0148558X0502000201

Bergstresser, D. \& Philippon, T., 2006, 'CEO incentives and earnings management', Journal of Financial Economics 80, 511-529. https://doi.org/10.1016/j.jfineco. 2004.10.011

Brennan, N.M. \& Solomon, J., 2008, 'Corporate governance, accountability and mechanisms of accountability: An overview', Accounting, Auditing \& Accountability Journal 21, 885-906. https://doi.org/10.1108/09513570810907401

Brown, P. \& Tarca, A., 2011, 'Ten years of IFRS: Practitioners' comments and suggestions for research', Australian Accounting Review 22(4), 319-330. https://doi.org/ 10.1111/j.1835-2561.2012.00198.x

Bushee, B.J., 2001, 'Do institutional investors prefer near-term earnings over longterm value?', Contemporary Accounting Research 18(2), 207-246.

Capkun, V., Collins, D. \& Jeanjean, T., 2012, Does adoption of IAS/IFRS deter earnings management?, Department of Accounting and Management Control, Paris.

Christensen, H., Lee, E. \& Walker, M., 2007, 'Cross-sectional variation in the economic consequences of international accounting harmonization: The case of mandatory IFRS adoption in the U.K.', The International Journal of Accounting 42, 341-379. IFRS adoption in the U.K.', The International
https://doi.org/10.1016/j.intacc.2007.09.007

Collin, S., Tagesson, T., Andersson, A., Cato, J. \& Hansson, K., 2009, 'Explaining the choice of accounting standards in municipal corporations: Positive accounting theory and institutional theory as competitive or concurrent theories', Critical Perspectives on Accounting 20(2), 141-174. https://doi.org/10.1016/j.cpa.2008.09.003

Companies Act, 2008, South African Companies Act No. 71 of 2008, Companies Act (2008), Republic of South Africa.

Creswell, J., 2003, Research design: Qualitative, quantitative, and mixed methods approaches, 2 nd edn., Sage, London.

Creswell, J.W. \& Clark, V.L.P., 2007, Designing and Conducting Mixed Method Research, Sage Publications, London.

Danjou, P., 2013, An update on International Financial Reporting Standards (IFRSs), viewed 12 February 2013, from http://www.ifrs.org/Features/Pages/An-Updateon-IFRSs-by-Philippe Danjou.aspx

Daske, H., Hail, L., Leuz, C. \& Verdi, R., 2006, 'Mandatory IFRS reporting around the world: Early evidence on the economic consequences', Journal of Accounting Research 46, 1085-1142.

Degeorge, F., Patel, J. \& Zeckhauser, R., 1999, 'Earnings management to exceed thresholds', The Journal of Business 72(1), 1-33. https://doi.org/10.1086/209601

Delvaille, P., Ebbers, G. \& Saccon, C., 2011, 'International financial reporting convergence: Evidence from three continental European countries', Accounting in convergence: Evidence from three continental European countries', A
Europe 2(1), 137-164. https://doi.org/10.1080/09638180500379103

Fields, T., Lys, T. \& Vincent, L., 2001, 'Empirical research on accounting choice', Journal of Accounting and Economics 31(1), 255-307. https://doi.org/10.1016/S01654101(01)00028-3

Gelter, M. \& Kavame, Z., 2014, Whose Trojan horse? The dynamics of resistance against IFRS, viewed 25 January 2015, from http://papers.ssrn.com/sol3/papers. cfm?abstract_id $=2418356$

Gietzmann, M. \& Trombetta, M., 2003, 'Disclosure interactions: Accounting policy choice and voluntary disclosure effects on the cost of raising outside capital', Accounting and Business Research 33(3), 187-205. https://doi.org/10.1080/0001 4788.2003.9729646

Guerreiro, M., Rodrigues, L. \& Craig, R., 2012, 'Voluntary adoption of International Financial Reporting Standards by large unlisted companies in Portugal - Institutional logics and strategic responses', Accounting, Organisations and Society 37, 482-499. https://doi.org/10.1016/j.aos.2012.05.003

Holthausen, R. \& Leftwich, R., 1983, 'The economic consequences of accounting choice', Journal of Accounting Economics 5, 77-117. https://doi.org/10.1016/01654101(83)90007-1

Hopwood, A., 1987, 'The archaeology of accounting systems', Accounting, Organisations and Society 12(3), 207-234. https://doi.org/10.1016/0361-3682(87)90038-9

Hunt, A., 1997, Earnings volatility, earnings management, and equity value, viewed 25 September 2014, from http://faculty.washington.edu/shevlin/hms2vol.pdf 
IASB, 2011, A guide through IFRS, IFRS Foundation, London, UK.

IASB, 2013, The use of 'business model' in the conceptual framework, IFRS Foundation, London, UK, pp. 1-5.

IFRS Foundation, 2013, International Financial Reporting Standards, viewed 29 October 2013, from http://www.ifrs.org/Current-Projects/IASB-Projects/ Conceptual-Framework/Meeting-Summaries-and-Observer-Notes/Pages/IASB February-2013

Jermakowicz, E. \& Gornik-Tomaszweski, S., 2006, 'Implementing IFRS from the perspective of EU publicly traded companies', Journal of International Accounting, Auditing and Taxation 15, 170-196. https://doi.org/10.1016/j.intaccaudtax.2006.08.003

JSE, 2013, JSE Listing requirements, viewed 04 February 2014, from http://www.jse. co.za/How-To-List/Listing-requirements/JSE-listing-requirements.aspx

Khlif, H., Hussainey, K. \& Achek, I., 2015, 'The effect of national culture on the association between profitability and corporate social and environmental disclosure: A meta-analysis', Meditari Accountancy Research 23(3), 296-321. https://doi.org/10.1108/MEDAR-12-2014-0064

Larson, R. \& Street, D., 2004, 'Convergence with IFRS in an expanding Europe: Progress and obstacles identified by large accounting firms' survey', Journal of Internationa Accounting, Auditing and Taxation 13, 89-119. https://doi.org/10.1016/j. intaccaudtax.2004.09.002

Laux, C. \& Leuz, C., 2009, 'The crisis of fair- value accounting: Making sense of the recent debate', Accounting, Organisations and Society 34, 826-834. https://doi. org/10.1016/j.aos.2009.04.003

Leedy, P. \& Ormrod, J., 2010, Practical research: Planning and design, Pearson Education Inc., NJ.

Liu, C., Yao, L., Hu, N. \& Liu, L., 2011, 'The impact of IFRS on accounting quality in a regulated market an empirical study of China', Journal of Accounting, Auditing \& Finance 26(4), 659-676. https://doi.org/10.1177/0148558X11409164

Marais, C., 2008, 'An evaluation of the South African equity markets' progress towards developed market behavior', viewed 28 November 2014, from http://repository. up.ac.za/bitstream/handle/2263/23147/dissertation. pdf? sequence $=1 \&$ isAllowed $=y$

Maroun, W., 2015, 'Culture, profitability, non-financial reporting and a meta-analysis: Comments and observations', Meditari Accountancy Research 23(3), 322-330. https://doi.org/10.1108/MEDAR-04-2015-0020

Maroun, W., 2017, 'Accounting for revenue using an accountability and business model framework: The case of the South African Institute of chartered accountants' professional examinations', South African Journal of Accounting Research 31(3), 240-254. https://doi.org/10.1080/10291954.2016.1205248

Maroun, W., Coldwell, D. \& Segal, M., 2014, 'SOX and the transition from apartheid to democracy: South African auditing developments through the lens of modernity theory', International Journal of Auditing 18(3), 206-212. https://doi.org/10.1111/ ijau.12025

Maroun, W. \& Jonker, C., 2014, 'Critical and interpretive accounting, auditing and governance research in South Africa', Southern African Journal of Accountability and Auditing Research 16, 51-62.

O’Dwyer, B., Owen, D. \& Unerman, J., 2011, 'Seeking legitimacy for new assurance forms: The case of assurance on sustainability reporting', Accounting, Organizations and Society 36, 31-52. https://doi.org/10.1016/j.aos.2011. 01.002
Qu, S. \& Dumay, J., 2011, 'The qualitative research interview', Qualitative Research in Accounting \& Management 8(3), 238-264. https://doi.org/10.1108/1176609 1111162070

Rosenfeld, P., 2000, 'What drives earnings management? It is GAAP itself', Journal of Accountancy 1-3.

Rowley, J., 2012, 'Conducting research interviews', Management Accounting Research 35, 260-271. https://doi.org/10.1108/01409171211210154

Saidin, S., Badara, M. \& Danrimi, M., 2014, 'The effect of acceptability and enforceability of International Financial Reporting Standards (IFRS) on global accounting standard convergence', Mediterranean Journal of Social Sciences 5(10), 295-302. https://doi.org/10.5901/mjss.2014.v5n10p295

Schipper, K., 2005, 'The introduction of International Accounting Standards in Europe: Implications for international convergence', European Accounting Review 14(1), 101-126. https://doi.org/10.1080/0963818042000338013

Shaffer, S., 2010, 'Fair value accounting: Villian or innocent victim', viewed 04 November 2013, from http://papers.ssrn.com/sol3/papers.cfm?abstract_id=1543210

Stent, W., Bradbury, M. \& Hooks, J., 2013, 'What firms' discretionary narrative disclosures reveal about the adoption of International Financial Reporting Standards', Australian Accounting Review 23(66), 252-263. https://doi.org/10.1111/auar.12002

Thomson, 2013, What is earnings management, viewed 22 September 2014, from http://www.swlearning.com/pdfs/chapter/0324223250_1.PDF

Tran, L., 2012, 'The role of the FASB and the IASB in establishing fair value measurements', viewed 01 October 2013, from http://www.willamette.com/ insights_journal/12/winter_2012_2.pdf

Tremblay, M. \& Gendron, Y., 2011, 'Governance prescriptions under trial: On the interplay between the logics of resistance and compliance in audit committees', Critical Perspectives on Accounting 22, 259-272. https://doi.org/10.1016/j.cpa.2010.10.003

Tuckett, A., 2004, Qualitative research sampling: The very real complexities, viewed 28 October 2014, from http://web.a.ebscohost.com.innopac.wits.ac.za/ehost/ pdfviewer/pdfviewer?sid=5918edd8-8177-44a7-a27e-018320b9e1e8\%40sessio nmgr4001\&vid=1\&hid $=4114$

van Zijl, W. \& Maroun, W., 2017, 'Discipline and punish: Exploring the application of IFRS 10 and IFRS 12', Critical Perspectives on Accounting 44, 42-58. https://doi. org/10.1016/j.cpa.2015.11.001

Verhoef, G., 2012, Economic integration through knowledge integration, the impact of IFRS on the globalization of accounting firms and corporate business in South Africa, viewed 28 November 2014, from https://apebh2012.files.wordpress com/2011/05/verhoef-economic-integration-through-knowledge-integration.pdf

Wagenhofer, A., 1990, 'Voluntary disclosure with a strategic opponent', Journal of Accounting and Economics 12, 341-363. https://doi.org/10.1016/0165-4101(90) Accounting

Williams, C., 2007, 'Research methods', Journal of Business and Economic Research $5(3), 65-72$.

Zeghal, D. \& Mhedhbi, K., 2006, 'An analysis of the factors affecting the adoption of international accounting standards by developing countries', The International Journal of Accounting 41, 373-386. https://doi.org/10.1016/j.intacc.2006.09.009

Zehri, C. \& Abdelbaki, A., 2013, 'Does adoption of international accounting standards promote economic growth in developing countries?', International Open Journal of Economics 1(1), 1-13. 


\section{Appendix 1: List of abbreviations and acronyms}

\begin{tabular}{ll}
\hline List of abbreviations and acronyms with the \\
\hline Abbreviations and acronyms & Description \\
\hline CFO & Chief financial officer \\
Companies Act & South African Companies Act 71 of 2008 \\
Conceptual Framework & Conceptual Framework for Financial Reporting \\
EFRAG & European Financial Reporting Advisory Group \\
EU & European Union \\
FAS & Financial accounting standards \\
FASB & Financial Accounting Standards Board \\
GAAP & Generally Accepted Accounting Principles \\
HEPS & Headline earnings per share \\
IASB & International Accounting Standards Board \\
IFRS & International Financial Reporting Standards \\
IFRS 13 & International Financial Reporting Standards 13: \\
IFRS for SMEs & Fair Value Measurement \\
\hline IT & International Financial Reporting Standards for \\
JSE & Small and Medium Entities \\
PLC & Information technology \\
SAICA & Johannesburg Securities Exchange \\
SEC & Public limited company \\
USA & South Africa Institute of Chartered Accountants \\
\hline
\end{tabular}

